\title{
Separation and determination of lithium and manganese ions in healthy humans and multiple sclerosis patients based on nanographene oxide by ultrasound assisted-dispersive -micro solid-phase extraction
}

Seyed Majid Nabipour Haghighi ${ }^{\text {a }}$ and Negar Motakef Kazemi* ${ }^{* a}$

${ }^{a}$ Department of Medical Nanotechnology, Faculty of Advanced Sciences and Technology, Tehran Medical Sciences, Islamic Azad University, Tehran, Iran.

\section{A R T I C L E I N F O :}

Received 3 Sep 2021

Revised form 6 Nov 2021

Accepted 30 Nov 2021

Available online 29 Dec 2021

\section{Keywords:}

Lithium, Manganese,

Human samples,

Multiple sclerosis patients,

Nano graphene oxide,

Ultrasound assisted-dispersive-microsolid phase extraction

\begin{abstract}
A B S T R A C T
Lithium regulates the concentration of nitric oxide in the human body and a high dose of nitric oxide causes multiple sclerosis (MS). Also, the amount of manganese in the cerebrospinal fluid alters the metabolic reactions associated with MS. In this study, the mixture of the ammonium pyrrolidine dithiocarbonate (APDC), the hydrophobic ionic liquid [HMIM][PF6] and acetone coated on the surface of graphene oxide nanoparticles (GONPs) and used for separation Li and $\mathrm{Mn}$ in human samples by ultrasound assisted-dispersive-ionic liquid-micro-solid phase extraction technique (USA-DIL- $\mu$-SPE) at $\mathrm{pH}$ 6.0. After extraction and back-extraction, the amount of lithium and manganese in the blood, serum and urine samples was determined by the flame and the graphite furnace atomic absorption spectroscopy (F-AAS, GF-AAS), respectively. By optimizing parameters, the LOD, Linear ranges (LR) and preconcentration factor (PF) for $\mathrm{Li}$ and $\mathrm{Mn}$ ions were obtained $\left(0.03 \mathrm{mg} \mathrm{L}^{-1}, 0.25 \mu \mathrm{g} \mathrm{L}^{-1}\right),(0.1-0.4 \mathrm{mg}$ $\left.\mathrm{L}^{-1}, 0.08-1.5 \mu \mathrm{g} \mathrm{L}^{-1}\right)$ and 10 , respectively $(\% \mathrm{RSD}<5)$. The capacity adsorption of APDC/IL/GONPs and GONPs was achieved (148.5 mg $\left.\mathrm{g}^{-1}, 122.3 \mathrm{mg} \mathrm{g}^{-1}\right)$ and $\left(41.3 \mathrm{mg} \mathrm{g}^{-1}, 33.7 \mathrm{mg} \mathrm{g}^{-1}\right)$ for Li and Mn ions in a static system, respectively. This method was successfully validated by spiking samples and certified reference materials (CRM).
\end{abstract}

\section{Introduction}

Multiple sclerosis (MS) is the most common chronic inflammatory disease of the central nervous system (CNS), affecting more than 2 million people worldwide and is currently incurable. No drug can completely prevent progressive neurodegeneration, which is usually diagnosed with impaired movement function, bladder control, and cognitive processes $[1,2]$.

\footnotetext{
*Corresponding Author: Negar Motakef Kazemi

Email: motakef@iaups.ac.ir

https://doi.org/10.24200/amecj.v4.i04.158
}

Nitric oxide and its metabolites in the human body may be involved in the pathogenesis of several neurological disorders such as multiple sclerosis. Several studies have shown that lithium regulates NO levels in the central nervous system. High levels of compounds derived from reactive oxygen species (ROS) and reactive nitrogen species (RNS) have been detected in blood samples from RR-MS patients. In principle, increased production of $\mathrm{NO}$ and its metabolites in the peripheral blood of these patients has been shown [3]. Lithium may control NO formation in MS. There is a significant difference between 
serum lithium levels in RR-MS patients and healthy individuals. Extensive experimental and clinical studies show that lithium has protective effects on the pathogenesis of neurological diseases through several mechanisms (activation of nerve pathways, regulation of oxidative stress, anti-inflammatory responses, regulation of mitochondrial function, etc.). However, the use of high doses of lithium may lead to toxic effects [4]. Excessive accumulation of metal in the CNS stimulates oxidative stress, mitochondrial dysfunction, dysfunction of enzymes structural, regulatory, and catalytic functions in a variety of proteins, receptors, and carriers. Metals can cause nerve damage in $\mathrm{PD}, \mathrm{AD}$, and $\mathrm{MS}$ by disrupting mitochondrial function. The mechanism act with lower adenosine triphosphate (ATP) and produces ROS. Through these mechanisms, metals cause cell death by apoptotic or necrotic mechanisms [5]. Also, manganese is toxic to the $\mathrm{CNS}$ in excessive amounts. High manganese value can lead to a disease whose symptoms are similar to those of Parkinson's. Manganism is a type of extrapyramidal movement disorder of the Parkinson's type that has impaired motor and cognitive impairment due to neural processes [6]. Determination of metal ions in blood and body fluids can play an effective role in diagnosing the disease and various treatments. The characterization of nanomaterials in various fields, especially in medical science, caused to use for the determination of metals in human body fluids. Recently, the nanoparticles such as graphene oxide and activated carbon were used to measure the concentration of lead, mercury, lithium, silver and manganese ions in patients. For this purpose, a micro-extraction procedure based on solid-phase or liquid phase coupled to ultrasound was used to measure ions by atomic absorption spectroscopy [7]. Due to the toxicity of $\mathrm{Li}$ and $\mathrm{Mn}$ in the human body, its concentration must be determined in blood, serum and urine samples. Many technologies have been used for $\mathrm{Li}$ and $\mathrm{Mn}$ determination in different samples including, the isotope dilution atomic absorption spectrometry (ID-ET-AAS) for Li determination in serum samples. ID-ET-AAS based on the partially resolved isotope shift was done by graphite furnace atomic absorption spectrometer [8]. Also, flame emission(FES), flame atomic absorption spectroscopy (F-AAS) and ionselective electrode (ISE) were used for lithium determination in human patients $[9,10]$. The concentration of beryllium, copper, chromium, cobalt, nickel, magnesium and iron in the blood of MS patients was determined by ICP-MS [11]. Moreover, the inductively coupled plasma sector field mass spectrometry (ICP-SFMS) and MCICP-MS was used for Li determination in serum samples $[12,13]$. The Li in human samples was determined by high-resolution atomic absorption spectrometry (HR-AAS) and machine learning data(MLD) [14]. In addition, Mn ions in herbal teas were evaluated by FAAS and ICP-OES [15]. The cation exchange chromatography coupled to field ICP-MS was used for Mn determination in cerebrospinal fluid [16]. As in previous research, the $\mathrm{Li}$ and $\mathrm{Mn}$ were determined in metals of human blood samples by AAS after sample preparation techniques. Recently, the different treatments such as; the dispersive liquid-liquid microextraction (DLLME) [17], the cloud point extraction procedure (CPE) [18], and the solidphase extraction (SPE) [19, 20] were used for metal analysis in various samples. Among them, the SPE as low cost, simple and good recovery is preferred to other methods.

In this research, a new adsorbent based on APDCIL/GONPs was used for extraction of $\mathrm{Li}$ and $\mathrm{Mn}$ in human biological samples by USADIL- $\mu$-SPE procedure. $\mathrm{Li}$ and $\mathrm{Mn}$ ions were determined by F-AAS and ET-AAS, respectively after sample treatment. The method was validated by spiking real samples and CRM analysis in human blood, serum and urine samples.

\section{Experimental}

\subsection{Instruments}

The different instruments include a magnetic stirrer (Four E'S Scientific, model MI0102003) 
with a variable speed made in china, a digital scale with an accuracy of one-thousandth of a gram made in Japan, a digital $\mathrm{pH}$ meter model 744 made in Switzerland, centrifuge with 3500$4000 \mathrm{rpm}$ made in Iran (IRANLABXPO), hematocrit centrifuge with $12,000 \mathrm{rpm}(\mathrm{AHN}$ myLab ${ }^{\circledR}$ hematocrit centrifuge, AHN Biotechnologie GmbH, Germany), a magnetic healer, oven (Iran Lab), Austrian microwave device (Anton Paar, Vienna Austria), the sharp polyethene pipes and Pyrex glass, the tube and balloon mixer, and the automatic sampling for different volumes between $0.01 \mathrm{~mL}$ to $1 \mathrm{~mL}$ were used in this research. The Mn and Li concentration was determined by flame atomic absorption spectrometer (FAAS, GBC 906, double beam, Aus.). The air-acetylene $\left(\mathrm{C}_{2} \mathrm{H}_{2}\right)$, the deuterium lampas was used for $\mathrm{Li}$ evaluation. The limit of detection (LOD) and linear range ofF-AAS for Liions in standard solutions was obtained $0.32 \mathrm{mg}$ $\mathrm{L}^{-1}$ and 1-4 $\mathrm{mg} \mathrm{L}^{-1}$, respectively. The light of HCL for lithium was adjusted by maximum energy at a wavelength of $670.8 \mathrm{~nm}$, slit of $0.5 \mathrm{~nm}$ and 5.0 $\mathrm{mA}$. The ultra-trace analyzer, the electrothermal atomic absorption spectrophotometer (ET-AAS, GBC, Aus.) was used for the determination of Mn in human blood samples. The limit of detection (LOD) and linear range of $\mathrm{Mn}$ ions with ETAAS was obtained 0.27 $\mu \mathrm{g} \mathrm{L}^{-1}$ and 2.5-15 $\mu \mathrm{g} \mathrm{L}^{-1}$, respectively The Avanta software was used for calculating absorption results by the F-AAS and ET-AAS.

\subsection{Reagents}

The ultra-pure reagents were purchased from the Merck or Sigma Companies (Germany). All standard solutions and samples were diluted by ultra-pure distilled water (DW, $\mathrm{R} \geq 18 \mathrm{M} \Omega \mathrm{cm}^{-1}$ ) from Millipore (Bedford, USA). The standard stock solution of lithium (LiCl, CASN: 744741-8) and manganese ( $\mathrm{MnCl}_{2}$, CAS N.:18930240-7) was purchased from Sigma Aldrich (1000 $\mathrm{mg} \mathrm{L}^{-1}$ in $1 \%$ nitric acid $\left.500 \mathrm{~mL}\right)$. The calibration standard solutions of lithium $(0.1$, $\left.0.2,0.3,0.4 \mathrm{mg} \mathrm{L}^{-1}\right)$ and manganese (0.1-1.5 $\mu \mathrm{g}$
$\mathrm{L}^{-1}$ ) were prepared by diluting of stock solution with DW (1000 mg L $\left.{ }^{-1}\right)$. Nitric acid $\left(\mathrm{HNO}_{3}\right)$, hydrochloric acid (HCl, CAS N.: 7647-01-0), sodium hydroxide (NaOH, CAS N.; 1310-73-2), potassium hydroxide (KOH, CAS N.: 1310-583 ), and all other reagents were purchased from Merck, Germany. The $\mathrm{pH}$ was adjusted by suitable buffer solutions. The different buffer solutions such as the sodium phosphate $\left(\mathrm{H}_{3} \mathrm{PO}_{4} / \mathrm{NaH}_{2} \mathrm{PO}_{4}\right.$, $\left.0.15 \mathrm{~mol} \mathrm{~L}^{-1}\right)$ for $\mathrm{pH} 1.5-3$, the ammonium acetate buffer $\left(\mathrm{CH}_{3} \mathrm{COOH} / \mathrm{CH}_{3} \mathrm{COONa}\right)$ for $\mathrm{pH} 4-5.5$, the sodium borate $\left(\mathrm{NaBO}_{2} / \mathrm{HCl}\right)$ for $\mathrm{pH} 7$ and the ammonium chloride $\left(\mathrm{NH}_{3} / \mathrm{NH}_{4} \mathrm{Cl}\right)$ were used for $\mathrm{pH}$ 8-10. Graphene oxide was prepared by the Petroleum Industry Research Institute (RIPI) and coated with a mixture of ionic liquid/APDC (99\%, ammonium pyrrolidine dithiocarbonate, CAS N.: 5108-96-3, EC Number: 225-834-4) and acetone. Hydrophobic ionic liquid (1-Hexyl3-methylimidazolium hexafluorophosphate, [HMIM][PF$\left.{ }_{6}\right]$, CAS N.: 304680-35-1) was prepared from Sigma, Germany.

\subsection{Synthesis of APDC-IL coated on graphene oxide}

The graphite oxide was prepared by modified Hummer technique by oxidation of natural graphite powder in the laboratory of RIPI. The GO was prepared by peeling off graphite oxide. First, $5 \mathrm{~g}$ of graphite powder and $2.5 \mathrm{~g}$ of $\mathrm{NaNO}_{3}$ were combined with $120 \mathrm{~mL} \mathrm{H}_{2} \mathrm{SO}_{4}$ $(98 \%)$ and shaken vigorously for $30 \mathrm{~min}$ in an ice bath $\left(0-5{ }^{\circ} \mathrm{C}\right)$. Simultaneously with stirring, $15 \mathrm{~g}$ of $\mathrm{KMnO}_{4}$ was gradually added, and the temperature was tuned at below $15{ }^{\circ} \mathrm{C}$. The ice bath was then removed, and the mixture was stirred at $35{ }^{\circ} \mathrm{C}$ until it gradually turned brown form and then diluted gently with $250 \mathrm{~mL}$ of water. The reaction temperature rose rapidly to $98{ }^{\circ} \mathrm{C}$ with boiling and its colour changed to dark brown. Then, $30 \% \mathrm{H}_{2} \mathrm{O}_{2}$ solution was added, and the colour of the mixture changed to a bright yellow colour, indicating complete oxidation of graphene. The graphene oxide was washed by rinsing and centrifugation with 
dilute hydrochloride solution and then continued several times with deionized distilled water to neutralize the filtered solution. The graphene oxide suspension was centrifuged and sonicated for 15 minutes at $3000 \mathrm{rpm}$ to obtain graphene oxide nanosheets. Finally, the prepared GONPs was air-dried for two hours in two stages at 55 ${ }^{\circ} \mathrm{C}$. Ammonium pyrrolidine dithiocarbamate (APDC) was mixed with ionic liquid 1-hexyl3-methylimidazolium hexafluorophosphate (hydrophobic) in the presence of acetone at 25 ${ }^{\circ} \mathrm{C}$ for 10 minutes. Then an organic mixture (ionic liquid, acetone, ammonium pyrrolidine dithiocarbamate) was used at $55^{\circ} \mathrm{C}$ for coating of graphene oxide (IL /APDC-NGO) [21-23].

\subsection{General Procedure}

By procedure, a sample of lithium was prepared by diluting $1 \mathrm{ml}$ of blood, urine and serum sample with DW up to $10 \mathrm{~mL}$. Also, $10 \mathrm{~mL}$ of human biological samples were used for manganese separation at optimized pH. $25 \mathrm{mg}$ of APDC/IL/ GONPs adsorbent was used to separate lithium and manganese ions from the blood, serum and urine of MS patients by the ultrasound assisted-dispersive-ionic liquid-micro-solid phase extraction technique (USA-DIL- $\mu$-SPE). The standard solution of lithium $(0.1-0.4 \mathrm{mg}$ $\left.\mathrm{L}^{-1}\right)$ and manganese $\left(0.1-1.5 \mu \mathrm{g} \mathrm{L}^{-1}\right)$ as the lower and upper limit of quantification (LLOQ, ULOQ) were used. After adding adsorbent to the human samples, it was placed in an ultrasonic bath for 5 minutes and the lithium and manganese ions were physically and chemically adsorbed by a sulfur bond of APDC ligand and the surface of the graphene oxide, respectively $\left(\mathrm{Mn}^{+2} / \mathrm{Li}^{+} \rightarrow \mathrm{NGO}\right.$; $\left.\mathrm{Mn}^{+2} / \mathrm{Li}^{+} \rightarrow: \quad \mathrm{S}-\mathrm{IL}-\mathrm{NGO}\right)$. By the proposed

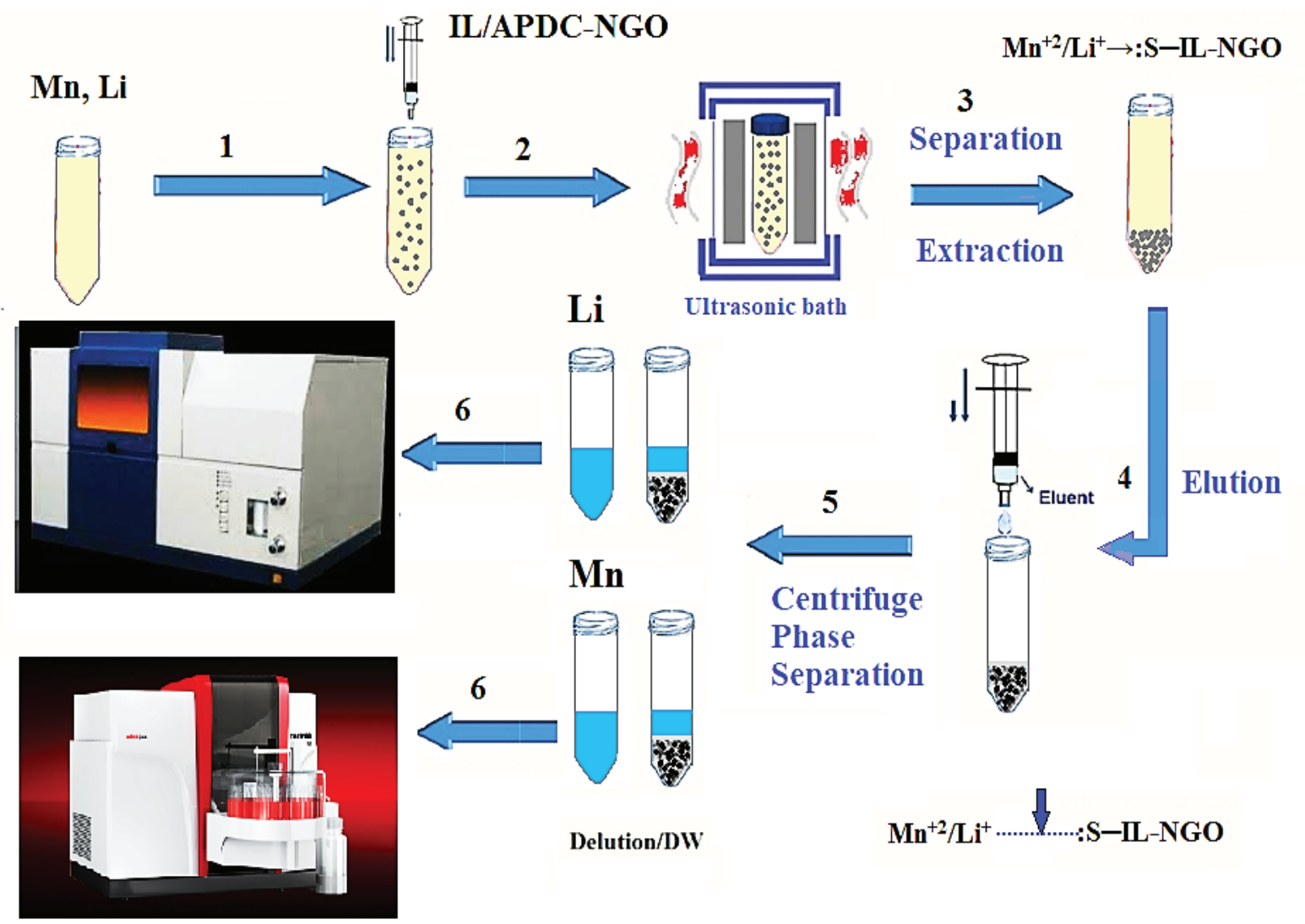

Fig. 1. Determination and separation lithium and manganese ions in human biological samples based on APDC/IL/GONPs by USA-DIL- $\mu$-SPE procedure 
procedure, lithium $(\mathrm{Li})$ and manganese $(\mathrm{Mn})$ ions are extracted by coordinate covalent bond at $\mathrm{pH} 5$ and 6, respectively (more than 95\%). The results showed us, at high $\mathrm{pH}$, lithium and manganese ions were precipitated as hydroxide ions $\left(\mathrm{Mn}(\mathrm{OH})_{2}\right.$ and $\mathrm{LiOH})$. After the separated phase by centrifuging (3 $\mathrm{min}, 3500 \mathrm{rpm}$ ), the extracted lithium and manganese ions were trapped in the bottom of the conical tube by IL/GONPs. Then, the upper liquid phase was set aside with an auto-sampler and the loaded ions on the adsorbent (APDC/IL/GONPs) were back-extracted by the nitric acid solution (500 $\mu \mathrm{L}, 0.3 \mathrm{M}$ ) by shaking and centrifuging for 1 minute. Finally, the concentration of lithium and manganese ions was determined by the F-AAS and ETAAS, respectively after diluting eluent up to $1 \mathrm{~mL}$ with $0.5 \mathrm{ml}$ of DW. Also, the extraction/separation of lithium and manganese ions based on GONPs in human biological samples and the standard solution was investigated in various $\mathrm{pH}$. For urine analysis, $10 \mathrm{~mL}$ of sample was used under similar conditions. For validation of the method, the standard reference materials (SRM) and spike samples were used for standard and human samples. For calibration of lithium and manganese ions, $10 \mathrm{~mL}$ of a standard aqueous sample containing lithium $(0.05,0.1$, $0.2,0.3$ and $\left.0.4 \mathrm{mg} \mathrm{L}^{-1}\right)$ and manganese $(0.1,0.2$, 0.4. $\left.0.5,1.0,1.5 \mu \mathrm{gL}^{-1}\right)$ were prepared from stock

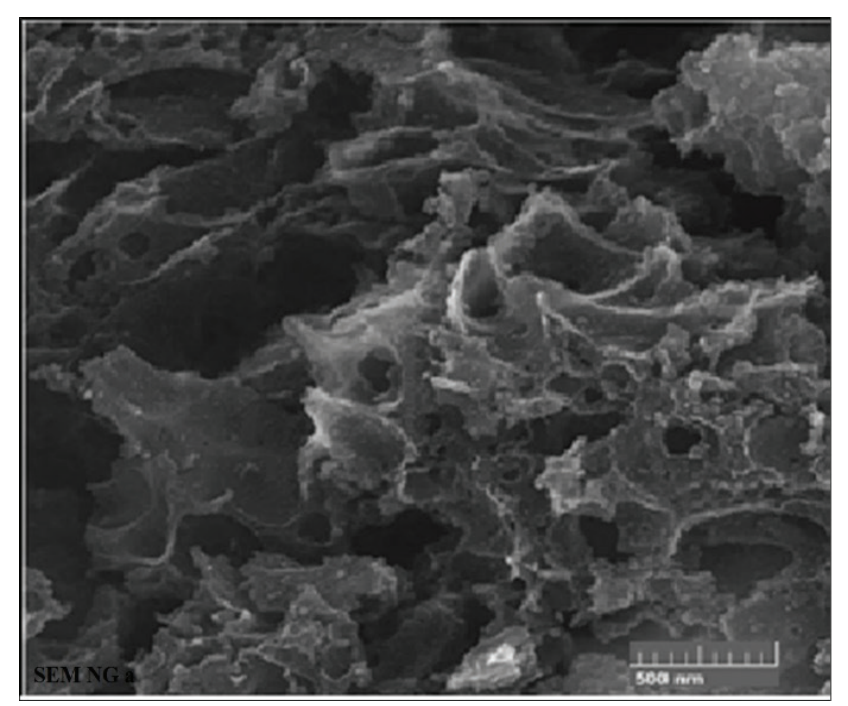

Fig. 2a.SEM image of APDC/IL/GONPs solutions. In addition, the ICP-MS were used to validate the real samples.

\section{Results and Discussion}

\subsection{Characterization of APDC/IL/graphene oxide}

Fourier transform infrared (FT-IR) spectra were recorded by a Perkin Elmer spectrophotometer. The X-ray diffraction (XRD) was obtained based on a Panalytical X'Pert PRO X-ray diffractometer. The Bruker (D) FRA-106/S spectrometer was used for Raman spectra. Scanning electron microscopy (SEM) images were reported by a Tescan Mira3. The transmission electron microscopes images (TEM, JEM 2100 plus) was achieved by JEOL Company, Germany.

\subsubsection{Electron microscope images}

As Figure 2(a, b) and 3(a, b), the scanning electron microscopy (SEM) and transmission electron microscope (TEM) images show that the APDC/ IL/GONPs and GONPS has similar multi-layered with a smooth surface and some with folds. Wrinkled areas are at the APDC/IL/GONPs and GONPS level due to the presence of oxygenated functional groups (such as carboxyl, hydroxyl, and carbonyl). The APDC/IL/GONPs and GONPS both consist of randomly accumulated and wrinkled thin sheets.

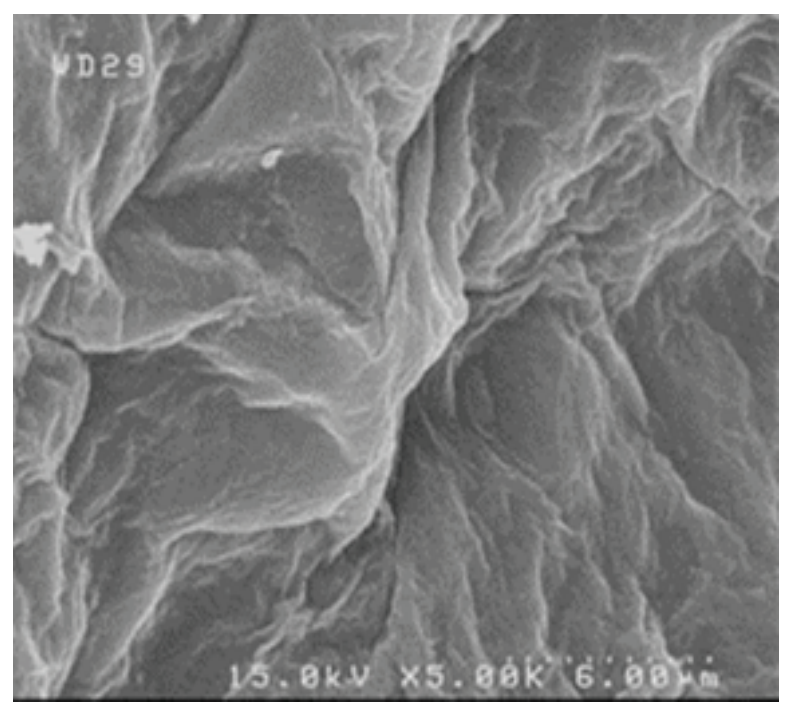

Fig. 2b.SEM image of GONPs 


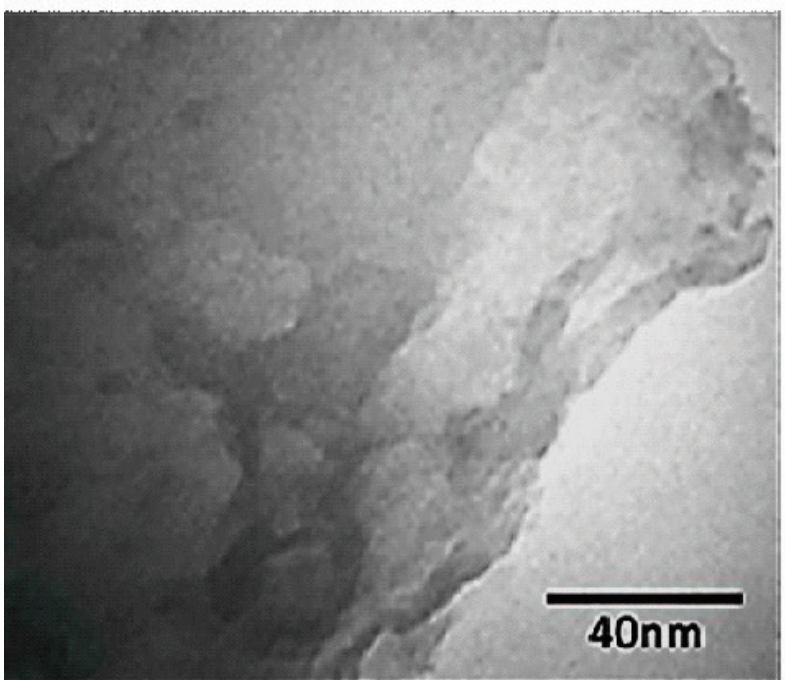

Fig. 3a.TEM image of APDC/IL/GONPs

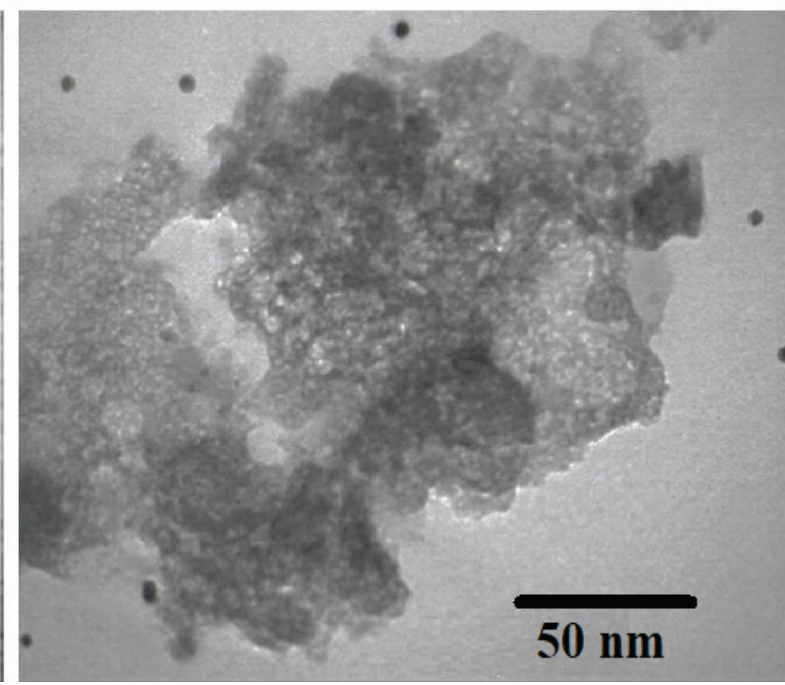

Fig. 3b.TEM image of GONPs

\subsubsection{XRD and FT-IR analysis}

In the XRD analysis of graphene oxide, a sharp peak was observed at $2 \theta=12.267(\mathrm{~d}=0.723)$ with the usual GONPs nanoparticle diffraction peak. The distance $\mathrm{d}$ increases from 0.33 to $0.72 \mathrm{~nm}$ after the conversion of graphite to graphene oxide nanoparticles, which may be due to the formation of abundant oxygenated functional groups on the graphene oxide surface. In addition, the peaks at $2 \theta=12^{\circ}$ and $2 \theta=42.58^{\circ}$ are related to the diffraction planes of (002) and (100) respectively, which can be observed in the XRD patterns of both GONPs

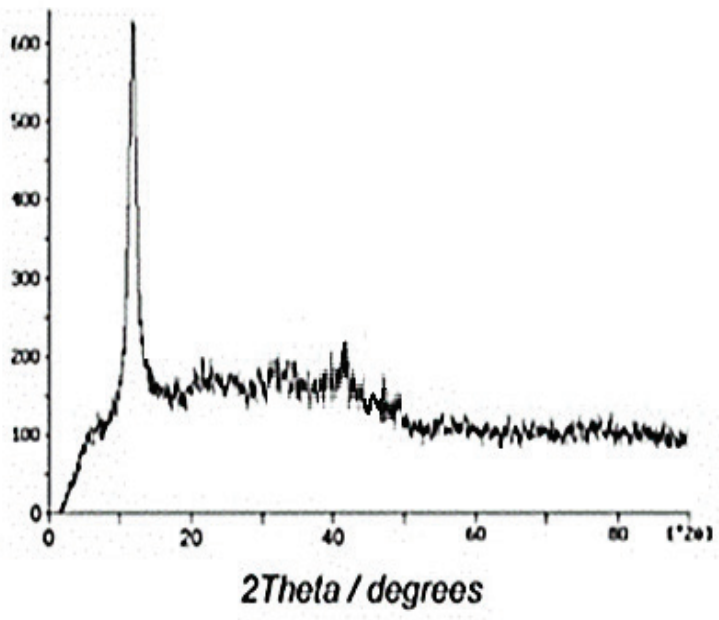

Fig. 4a. XRD of the GONPS

and APDC/IL/GONPs. It showed that the XRD intensity of the peak at $2 \theta=12^{\circ}$ for the APDC/IL-coated on GONPs was significantly decreased (Fig.4a and b).

Oxygenated functional groups on the surface of graphene oxide nanoparticles by FT-IR analysis can be seen in the following diagram. Accordingly, the groups $\mathrm{C}=\mathrm{O}$ and $\mathrm{COOH} / \mathrm{OH}$ are represented by the peak of $1728 \mathrm{~cm}^{-1}$ and $3300 \mathrm{~cm}^{-1}$, respectively. The C-O bonding is shown at peak $1011 \mathrm{~cm}^{-1}$ and the peak $\mathrm{C}=\mathrm{C}$ is located at $1590 \mathrm{~cm}^{-1}$ by FTIR. As physically coated APDC/IL on GONPs any peak wasn't added to FTIR of GO (Fig.5).

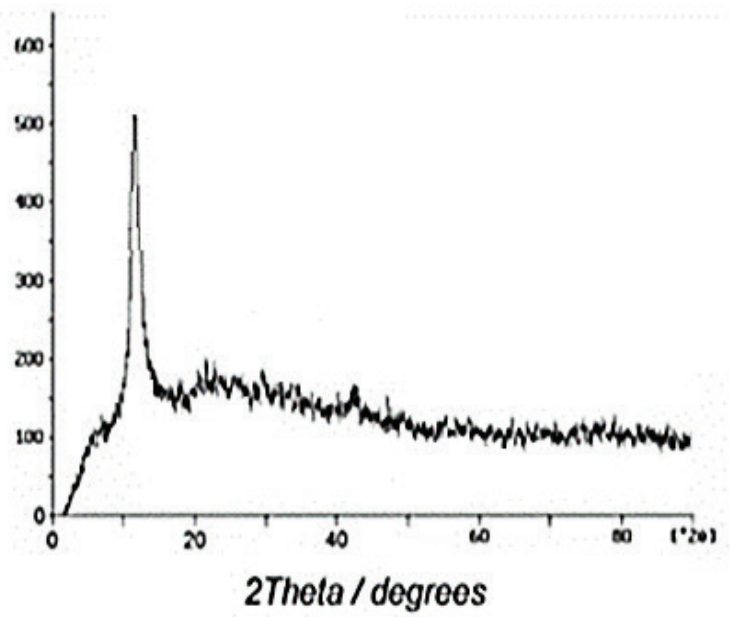

Fig. 4b. XRD of the APDC/IL/GONPS 


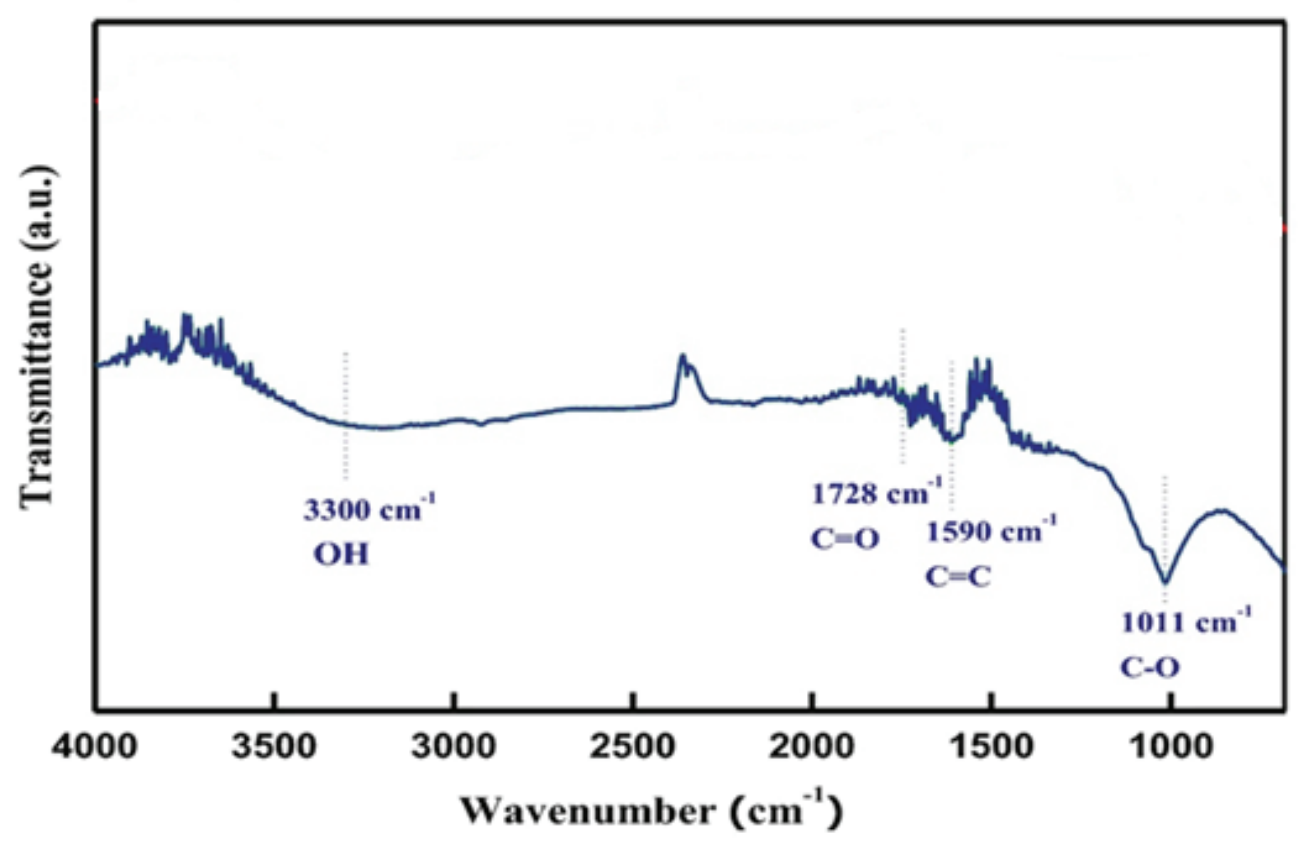

Fig.5. FT-IR analysis of the APDC/IL/GONPs

\subsection{Optimization of Method}

To achieve optimal conditions in solid-phase extraction for preconcentration/separation of lithium and manganese in human biological samples, the parameters such as $\mathrm{pH}$, the amount of sorbent, the sample volume, the amount of ionic liquid, the concentration of APDC ligand, the shaking and centrifuge time, were investigated.

\subsubsection{The pH optimization}

The $\mathrm{pH}$ effects on the extraction of $\mathrm{Li}$ and $\mathrm{Mn}$ ions by APDC/IL/GONPs. So, the various $\mathrm{pH}$ between 2-11 was studied for Li and Mn extraction in human biological matrixes. The results showed, the sulfur group on the surface of GONPs adsorbent was caused to extraction $\mathrm{Li}$ and $\mathrm{Mn}$ ions at $\mathrm{pH}$ of 5-7. Due to the mechanism, the extraction was reduced at $\mathrm{pH}<5$ and $\mathrm{pH}>7$. Therefore, we used $\mathrm{pH}=6$ for $\mathrm{Li}$ and $\mathrm{Mn}$ extraction in human biological samples (blood, serum, urine). The mechanism of absorption of Li and Mn ions was obtained based on the sulfur group (SH) on the surface of APDC/IL/GONPs. By a sulfur group of APDC, the coordinate covalent bond with $\mathrm{Li}$ and $\mathrm{Mn}$ ions in human liquid samples was achieved $\left(\mathrm{Mn}^{+2} / \mathrm{Li}^{+} \rightarrow: \mathrm{S}-\mathrm{IL}-\mathrm{NGO}\right)$. At $\mathrm{pH}<$ $\mathrm{pH}_{\mathrm{PZC}}$, the adsorbent had a positive charge and due to similarity charges between $\mathrm{Li}$ and $\mathrm{Mn}$ and adsorbent, the extraction was decreased. Also, in $\mathrm{pH} 5$ for $\mathrm{Li}$ and $\mathrm{pH} 6$ for $\mathrm{Mn}$, the surface of APDC/ IL/GONPS based on negatively charged (HS-) coordinated with a positive charge of $\mathrm{Li}$ and $\mathrm{Mn}$. At $\mathrm{pH}$ more than 7, Li and $\mathrm{Mn}$ ions have participated as hydroxyl forms $\left(\mathrm{Li} \mathrm{OH}, \mathrm{Mn}(\mathrm{OH})_{2}\right)$. Therefore, we used $\mathrm{pH}=6$ for further studies (Fig. 6).

\subsubsection{Optimization of adsorbent amount}

The efficient extraction of $\mathrm{Li}$ and $\mathrm{Mn}$ ions in human samples were studied by different amount of APDC/IL/GONPs. For this purpose, the various mass of APDC/IL/GONPs was evaluated at $\mathrm{pH}=6$. For Li and Mn extraction, 2-40 mg of APDC/IL/ GONPs in blood, serum, urine and standard solution were studied and optimized by the USA-DIL- $\mu$ SPE procedure. Based on the results, the efficient extractions for $\mathrm{Li}$ and $\mathrm{Mn}$ ions were obtained by 20 $\mathrm{mg}$ of adsorbent in human biological samples. So, $25 \mathrm{mg}$ of APDC/IL/GONPs was used for further study (Fig. 7). 


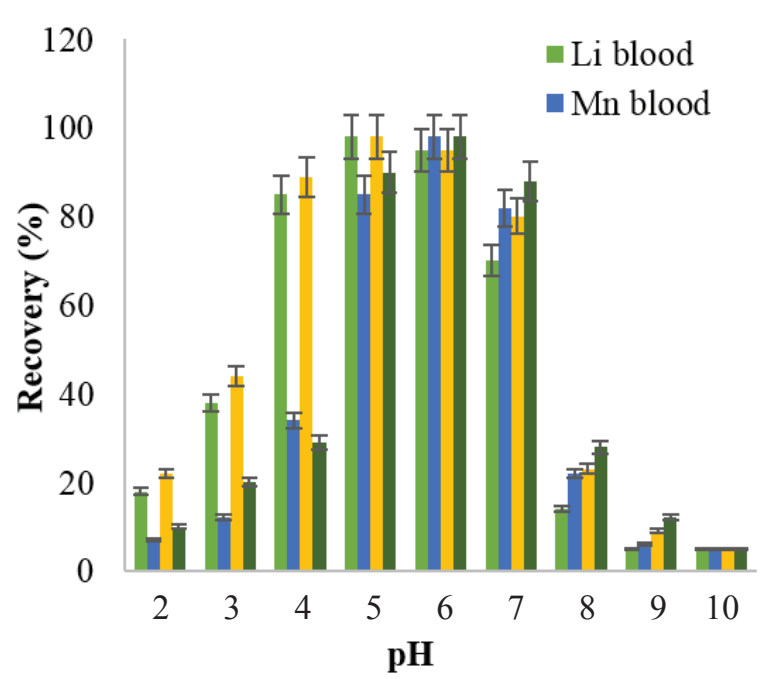

Fig.6. The effect of $\mathrm{pH}$ on $\mathrm{Li} / \mathrm{Mn}$ extraction

\subsubsection{Optimization of sample volume and eluent}

The effect of eluent on extraction $\mathrm{Li}$ and $\mathrm{Mn}$ ions based on APDC/IL/GONPs were studied at optimized $\mathrm{pH}$. At low $\mathrm{pH}$, the covalent bond between the metal and sulfur group was dissociated and the $\mathrm{Li}$ and $\mathrm{Mn}$ ions released into liquid phase. Therefore, the inorganic acid solutions with different concentrations and volumes $(\mathrm{HCl}$, $\mathrm{HNO}_{3}, \mathrm{H}_{3} \mathrm{PO}_{4}, \mathrm{H}_{2} \mathrm{SO}_{4}$ ) were used to evaluate the recovery of the back-extraction process for $\mathrm{Li}$ and

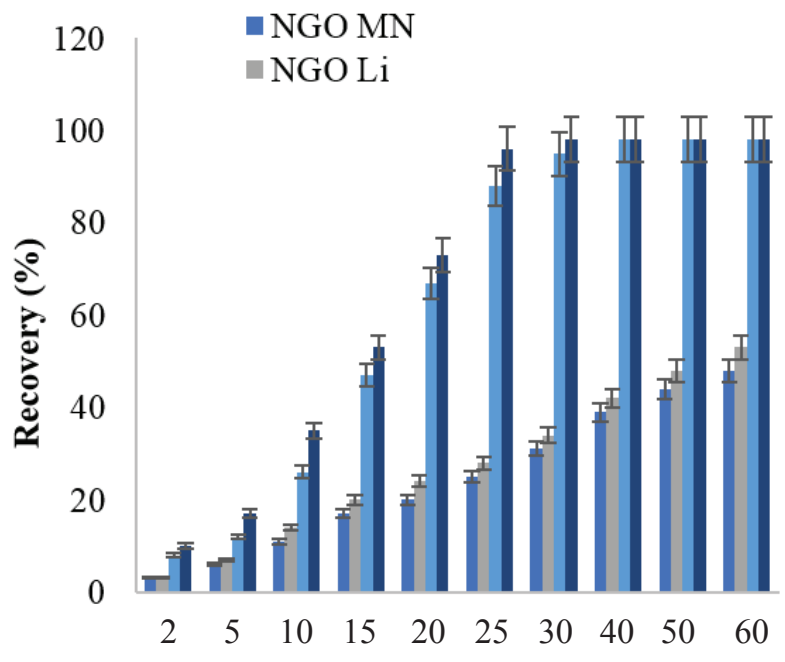

Amount of APDC/IL/GONPs (mg)

Fig.7. The effect of adsorbent mass on $\mathrm{Li} / \mathrm{Mn}$ extraction

Mn ions in human biological samples. The eluent concentrations between $0.2-2.0 \mathrm{~mol} \mathrm{~L}^{-1}$ was studied. The efficient extraction was obtained by $\mathrm{HNO}_{3}(0.5$ M, $0.25 \mathrm{~mL}$ ) (Fig. 8). Also, the volume of human samples and the standard solution was evaluated from $2.0 \mathrm{~mL}$ to $20 \mathrm{~mL}$ for $\mathrm{Li}$ and $\mathrm{Mn}$ concentration (0.1-0.4 $\left.\mathrm{m} \mathrm{L} \mathrm{L}^{-1}, 0.1-1.5 \mu \mathrm{g} \mathrm{L}^{-1}\right)$. As result, the high recovery occurred for $10 \mathrm{~mL}$ of human biological samples at pH 5-7 (Fig.9).

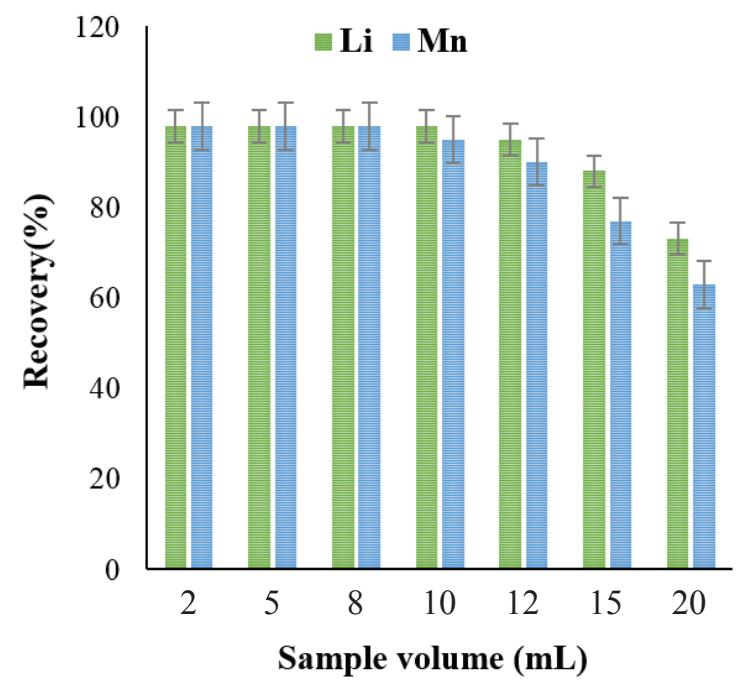

Fig.9. The effect of sample volume on $\mathrm{Li} / \mathrm{Mn}$ extraction
Fig.8. The effect of eluents

on $\mathrm{Li} / \mathrm{Mn}$ back-extraction

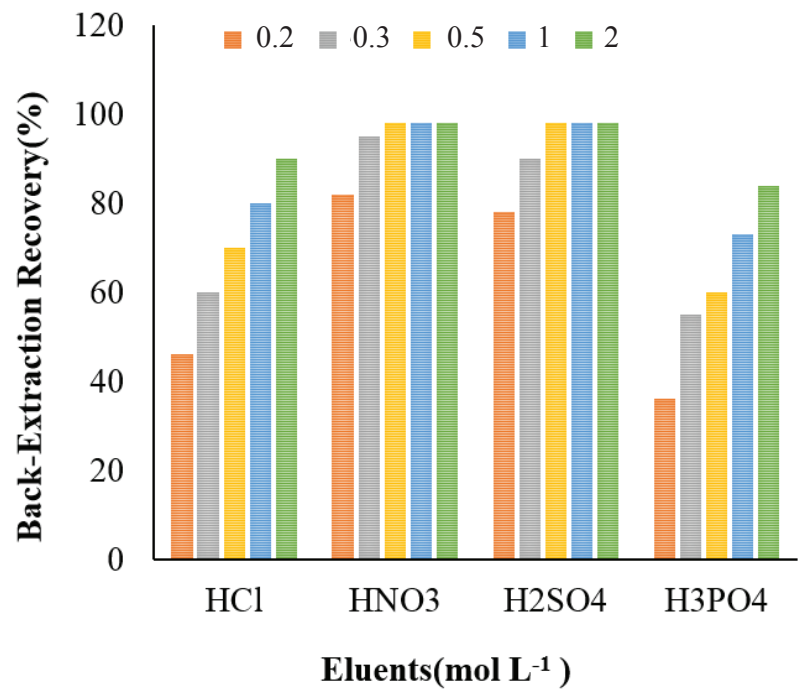




\subsubsection{Optimization of APDC ligand on adsorbent}

The concentration of APDC is one of the important parameters which should be optimized by the USA-DIL- $\mu$-SPE procedure method. For optimizing, $\quad 0.1 \times 10^{-6}-1.0 \times 10^{-6} \mathrm{~mol} \mathrm{~L}^{-6}$ of APDC ligand was used in the human biological sample. The results showed that, by increasing ligand concentration up to $0.5 \times 10^{-6} \mathrm{~mol} \mathrm{~L}^{-1}$, the recoveries are also increased. Figure 10 shows that $0.35 \times 10^{-6} \mathrm{~mol} \mathrm{~L}^{-1}$ of APDC was necessary to obtain the maximum extraction efficiency. So, the amount of chelating agent (APDC) between 0.1-1 $\mu \mathrm{mol} \mathrm{L}{ }^{-1}$ was investigated and $0.35 \mu \mathrm{mol} \mathrm{L}^{-1}$ was found the best amount for $\mathrm{Li}$ and $\mathrm{Mn}$ extraction.

\subsubsection{Optimization of time, reusability and absorption capacity}

The dispersion of APDC/IL/GONPs in human blood, serum, urine or standard solution had a critical role for extraction $\mathrm{Li}(\mathrm{I})$ and $\mathrm{Mn}(\mathrm{II})$. The time extraction depended on chemical adsorption between the sulfur group with metals at pH 5-7. By the USA-DIL- $\mu$-SPE procedure, the shaking time was examined between 1- $10 \mathrm{~min}$. It has occurred that the shaking of $5.0 \mathrm{~min}$ was the favourite time for ions extraction in samples. In this study, the time of shaking and centrifuging process were investigated and $5 \mathrm{~min}$ was found suitable for the shaking and $3 \mathrm{~min}$ for centrifuging process $(3500 \mathrm{rpm})$. After sonication for $5 \mathrm{~min}$, the APDC/IL/GONPs was trapped at the end of the conical tube and then the upper liquid phase was put out by auto-sampler. The reusability of APDC/IL/GONPs was obtained with many cycles extraction/back-extraction process. The results showed the adsorbent can be used for 12 cycles. The absorption capacities for cadmium depended on the characterization of APDC/IL/ GONPs and surface area. The absorption capacities of APDC/IL/GONPs for $\mathrm{Li}$ and Mn was achieved at $148.5 \mathrm{mg} \mathrm{g}^{-1}, 122.3 \mathrm{mg} \mathrm{g}^{-1}$, respectively.

\subsubsection{Interference cations and anions}

The effect of interference of ions on $\mathrm{Li}$ and $\mathrm{Mn}$ extraction in human biological samples were studied by the USA-DIL- $\mu$-SPE procedure. The concentrations of ions were added to the standard solution and human samples with lithium $(0.1$ - $\left.0.4 \mathrm{mg} \mathrm{L}^{-1}\right)$ and manganese $\left(0.1-1.5 \mu \mathrm{gL}^{-1}\right)$ at optimized conditions. The results showed the interference of ions couldn't decrease the efficient extraction of $\mathrm{Li}$ and $\mathrm{Mn}$ ions at $\mathrm{pH}=6$. (Table 1).

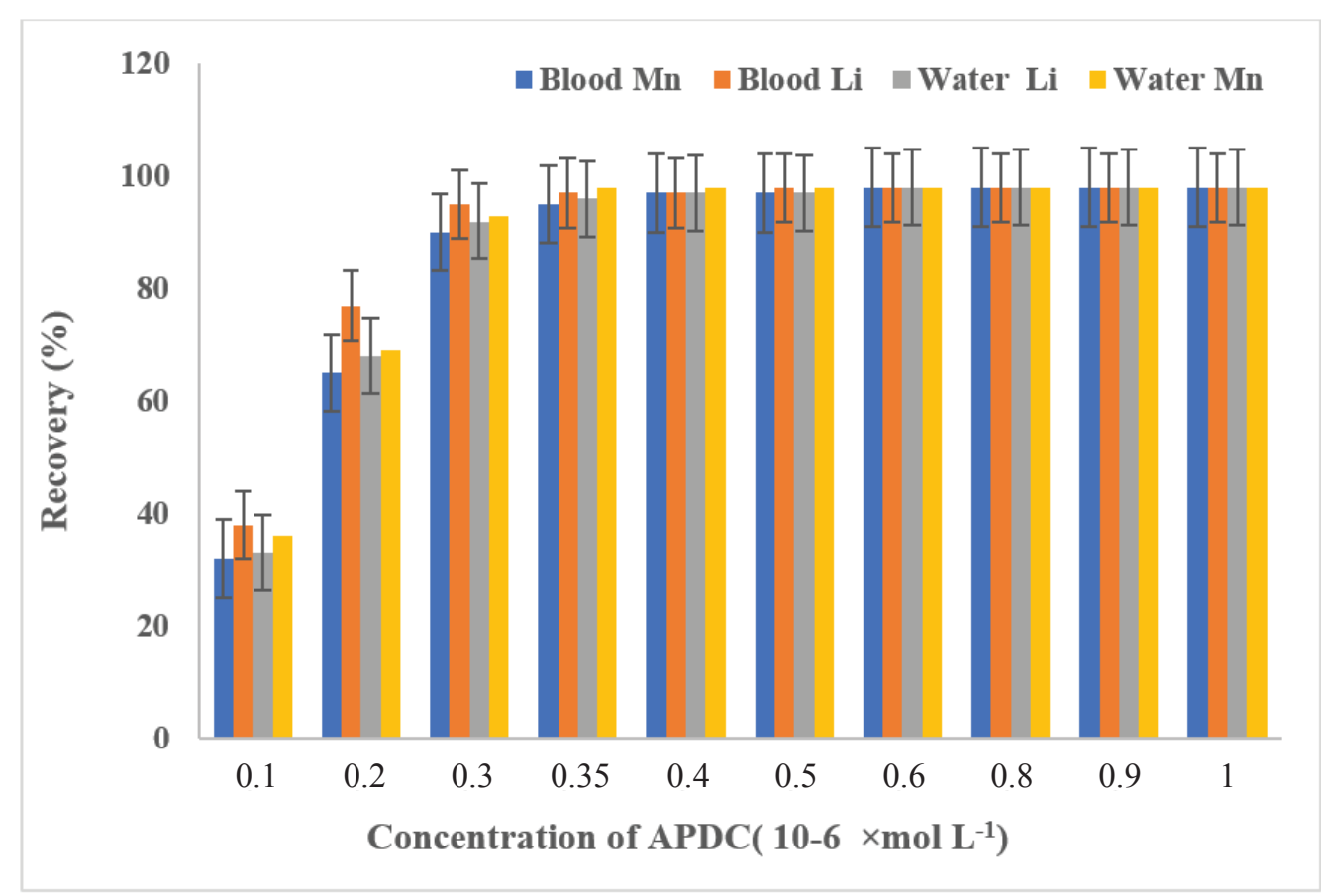

Fig.10. The effect of APDC concentration on Li /Mn extraction by the USA-DIL- $\mu$-SPE procedure 
Table 1. Interference cations and anions for $\mathrm{Li}$ and $\mathrm{Mn}$ extraction based on APDC/IL/GONPs by the USA-DIL- $\mu$-SPE procedure

\begin{tabular}{|c|c|c|c|c|}
\hline \multirow{2}{*}{ Interfering Ions(A) } & $\begin{array}{l}\text { Mean ratio } \\
\left(C_{A} / C_{L i(I)}\right)\end{array}$ & $\begin{array}{l}\text { Mean ratio } \\
\left(\mathrm{C}_{\mathrm{A}} / \mathrm{C}_{\mathrm{Mn}(\mathrm{II})}\right)\end{array}$ & Recovery (\%) & Recovery (\%) \\
\hline & $\mathbf{L i}$ & Mn & $\mathbf{L i}$ & Mn \\
\hline $\mathrm{Ni}^{2+}, \mathrm{Co}^{2+}, \mathrm{Se}^{2-}$ & 700 & 850 & 98.3 & 97.9 \\
\hline $\mathrm{Cr}^{3+}, \mathrm{Al}^{3+}, \mathrm{Ag}^{+}$ & 600 & 700 & 97.1 & 97.3 \\
\hline $\mathrm{I}^{-}, \mathrm{Br}, \mathrm{F}^{-}, \mathrm{Cl}^{-}$ & 1000 & 1100 & 97.8 & 98.4 \\
\hline $\mathrm{Na}^{+}, \mathrm{K}^{+}, \mathrm{Ca}^{2+}, \mathrm{Mg}^{2+}$ & 1200 & 1300 & 98.8 & 99.1 \\
\hline $\mathrm{CO}_{3}^{2-}, \mathrm{PO}_{4}^{3-}, \mathrm{NO}_{3}^{-}$ & 800 & 900 & 96.6 & 97.0 \\
\hline $\mathrm{Zn}^{2+}, \mathrm{Cu}^{2+}$ & 500 & 750 & 97.5 & 98.5 \\
\hline $\mathrm{Pb}^{2+}, \mathrm{Mo}^{2+}, \mathrm{Fe}^{2+}$ & 850 & 650 & 98.2 & 97.3 \\
\hline $\mathrm{Hg}^{2+}$ & 100 & 80 & 96.2 & 98.5 \\
\hline
\end{tabular}

\subsubsection{Method validation}

The concentration of $\mathrm{Li}$ and $\mathrm{Mn}$ in human blood and standard samples was determined by the USADIL- $\mu$-SPE procedure. The results were obtained based on the average of three analyses in blood samples. The rate of recovery showed that the proposed method has good accuracy and precision in the blood matrix. The recovery of spiked blood samples and the standard solution was more than $95 \%$. This method was satisfactory for the analysis of analytes in the human blood samples. Lithium and manganese concentrations were studied in
MS patients (40, subject) and healthy people (40, control) by the USA-DIL- $\mu$-SPE procedure. Mean lithium and manganese concentrations in control groups were significantly lower than MS patients. In addition, for the validation of the method, standard reference materials (SRM) for $\mathrm{Li}$ and Mn were examined by the adsorbent. The results of blood samples in standard reference samples (SRM) was satisfactorily confirmed the accurate concentration of $\mathrm{Li}$ and $\mathrm{Mn}$ ions. The following table shows the validation of the USA-DIL- $\mu$-SPE procedure based on APDC/IL/GONPs by spiking

Table 2. Validation of Mn determination in serum, blood and urine of MS patients by spiking samples with the standard solution by the USA-DIL- $\mu$-SPE procedure coupled to ET-AAS

\begin{tabular}{lccc}
\hline Sample & Added $\left(\boldsymbol{\mu g} \mathbf{L}^{-1}\right) \mathbf{M n}$ & ${ }^{a}$ Found $\left(\boldsymbol{\mu g} \mathbf{L}^{-1}\right) \mathbf{M n}$ & $(\%)$ Recovery \\
\hline \multirow{3}{*}{ Blood } & --- & $0.052 \pm 1.244$ & --- \\
& 0.5 & $0.117 \pm 1.729$ & 97.0 \\
\hline \multirow{3}{*}{ Serum } & 1.0 & $0.135 \pm 2.251$ & 100.7 \\
& --- & $0.063 \pm 1.036$ & --- \\
\hline \multirow{3}{*}{ Urine } & 0.5 & $0.072 \pm 1.531$ & 99.0 \\
& 1.0 & $0.203 \pm 1.984$ & 94.8 \\
\hline
\end{tabular}

${ }^{\mathrm{a}}$ Mean of three determinations of samples \pm confidence interval $(\mathrm{P}=0.95, \mathrm{n}=8)$ 
Table 3. Validation of Li determination in serum, blood and urine of MS patients by spiking samples with the standard solution by the USA-DIL- $\mu$-SPE procedure coupled to F-AAS

\begin{tabular}{|c|c|c|c|}
\hline Sample & Added $\left(\mathrm{mg} \mathrm{L}^{-1}\right) \mathrm{Li}$ & ${ }^{\mathrm{a}}$ Found $\left(\mathrm{mg} \mathrm{L}^{-1}\right) \mathbf{L i}$ & (\%) Recovery \\
\hline \multirow{3}{*}{ Blood } & --- & $0.07 \pm 1.56$ & --- \\
\hline & 1.0 & $0.12 \pm 2.61$ & 105.0 \\
\hline & 1.5 & $0.143 .02 \pm$ & 97.3 \\
\hline \multirow{3}{*}{ Serum } & --- & $0.12 \pm 2.16$ & --- \\
\hline & 1.0 & $0.15 \pm 3.11$ & 95.0 \\
\hline & 1.5 & $0.18 \pm 3.63$ & 98.0 \\
\hline \multirow{3}{*}{ Urine } & --- & $0.033 \pm 1.88$ & --- \\
\hline & 1.0 & $0.065 \pm 2.92$ & 104.0 \\
\hline & 1.5 & $0.084 \pm 3.33$ & 96.6 \\
\hline
\end{tabular}

${ }^{\mathrm{a}}$ Mean of three determinations of samples \pm confidence interval $(\mathrm{P}=0.95, \mathrm{n}=8)$

real samples and standard reference materials. ICP-MS was used to prepare standard reference samples (SRM) for validation of methodology. In this study, the method was validated by spiking real samples with a standard $\mathrm{Li}$ and $\mathrm{Mn}$ solution in blood, serum and urine samples (Table 2 and 3). Also, the $\mathrm{Li}$ and $\mathrm{Mn}$ were validated by ICP-MS. Validation of $\mathrm{Mn}$ and $\mathrm{Li}$ extraction in human samples was obtained based on APDC/II/ GONPs and standard reference materials (ICPMS analysis) by the USA-DIL- $\mu$-SPE procedure (Table 4 and 5). The results demonstrated the high extraction and recovery for $\mathrm{Li}$ and $\mathrm{Mn}$ in human blood matrixes. As intra and inter-day analysis, the 40 MS patients were compared to healthy people by the USA-DIL- $\mu$-SPE procedure (40 Men, 25-55 age, Iran) (Table 6). As Table 6, the concentration of lithium and manganese ions in the human body fluids for MS patients is significantly higher than the concentration of healthy people.

\subsubsection{Discussion}

The analysis of biological fluids is one of the most appropriate forms of evaluating environmental

Table 4. Validation methodology for Mn determination in human samples based on APDC/Il/ GONPs and standard reference materials (ICP-MS analysis) by the USA-DIL- $\mu$-SPE procedure

\begin{tabular}{lcccc}
\hline Samples $^{\mathbf{b}}$ & $\begin{array}{c}\text { Added } \\
\mu \mathrm{g} \mathrm{L}^{-1}\end{array}$ & $\begin{array}{c}\text { Certified } \\
\mu \mathrm{g} \mathrm{L}^{-1}\end{array}$ & $\begin{array}{c}\text { Found }^{\mathbf{a}} \\
\mu \mathrm{g} \mathrm{L}^{-1}\end{array}$ & $\mathbf{( \% )}$ Recovery \\
\hline Serum & ------ & $0.02 \pm 1.23$ & $0.06 \pm 1.21$ & 98.4 \\
& 1.0 & ------ & $0.12 \pm 2.18$ & 97.0 \\
\hline Blood & ----- & $0.01 \pm 0.79$ & $0.04 \pm 0.81$ & 102.5 \\
& 0.5 & ------ & $0.05 \pm 1.29$ & 96.0 \\
\hline Urine & ------ & $0.02 \pm 1.01$ & $0.06 \pm 0.98$ & 97.1 \\
& 1.0 & ------ & $0.09 \pm 1.99$ & 101.0 \\
\hline
\end{tabular}

${ }^{a}$ Mean of three determinations of samples \pm confidence interval $(\mathrm{P}=0.95, \mathrm{n}=8)$

${ }^{b} \mathrm{ICP}-\mathrm{MS}$ analyzer for blood, serum and urine as CRM $\left(\mu \mathrm{gL}^{-1}\right)$ 
Table 5. Validation methodology for Li determination in human samples based on APDC/Il/ GONPs and standard reference materials (ICP-MS analysis) by the USA-DIL- $\mu$-SPE procedure

\begin{tabular}{|c|c|c|c|c|}
\hline Samples $^{\text {b }}$ & $\begin{array}{l}\text { Added } \\
\text { mg L }^{-1}\end{array}$ & $\begin{array}{c}\text { Certified } \\
\mathrm{mg} \mathrm{L}^{-1}\end{array}$ & $\begin{array}{l}\text { Found }^{a} \\
\text { mg L }^{-1}\end{array}$ & (\%) Recovery \\
\hline \multirow[t]{2}{*}{ Serum } & ------ & $0.05 \pm 3.23$ & $0.15 \pm 3.14$ & 97.2 \\
\hline & 2.0 & ----- & $0.24 \pm 5.09$ & 97.5 \\
\hline \multirow[t]{2}{*}{ Blood } & ---- & $0.02 \pm 2.88$ & $0.13 \pm 2.86$ & 99.3 \\
\hline & 2.5 & ------ & $0.24 \pm 5.38$ & 100.8 \\
\hline \multirow[t]{2}{*}{ Urine } & ------ & $0.01 \pm 1.98$ & $0.11 \pm 2.02$ & 102.1 \\
\hline & 2.0 & ----- & $0.09 \pm 3.99$ & 98.5 \\
\hline
\end{tabular}

${ }^{a}$ Mean of three determinations of samples \pm confidence interval $(\mathrm{P}=0.95, \mathrm{n}=8)$ 'ICP analyzer for blood, serum and urine as CRM $\left(\mathrm{mgL}^{-1}\right)$

Table 6. The comparing of $\mathrm{Li}$ and Mn concentration in MS patients with healthy people by the USA-DIL- $\mu$-SPE procedure

\begin{tabular}{|c|c|c|c|c|c|c|c|c|}
\hline \multirow{2}{*}{$* *$ Sample } & \multicolumn{2}{|c|}{ *Patients MS } & \multicolumn{2}{|c|}{ * Control } & \multicolumn{4}{|c|}{ Patients MS } \\
\hline & $\begin{array}{c}\mathrm{Li} \\
\left(\mathrm{mgL}^{-1}\right)\end{array}$ & $\begin{array}{c}\mathrm{Mn} \\
\left(\mu \mathrm{gL}^{-1}\right)\end{array}$ & $\mathrm{Li}\left(\mathrm{mgL}^{-1}\right)$ & $\begin{array}{c}\mathrm{Mn} \\
\left(\mu \mathrm{gL}^{-1}\right)\end{array}$ & $\mathrm{rLi}$ & P value & $\mathrm{rMn}$ & $P$ value \\
\hline Blood & $\begin{array}{c}6.19 \pm \\
0.29\end{array}$ & $\begin{array}{l}14.24 \pm \\
0.65 * *\end{array}$ & $3.42 \pm 0.15$ & $\begin{array}{l}3.12 \pm \\
2.11^{* *}\end{array}$ & 0.202 & $<0.001$ & 0.115 & $<0.001$ \\
\hline Urine & $\begin{array}{c}4.35 \pm \\
0.22\end{array}$ & $\begin{array}{l}6.83 \pm \\
0.31 * *\end{array}$ & $1.75 \pm 0.07$ & $\begin{array}{c}2.42 \pm \\
0.90\end{array}$ & 0.196 & $<0.001$ & 0.076 & $<0.001$ \\
\hline Serum & $\begin{array}{c}7.47 \pm \\
0.33\end{array}$ & $\begin{array}{c}1.34 \pm \\
0.06\end{array}$ & $2.58 \pm 0.12$ & $\begin{array}{c}0.63 \pm \\
3.92\end{array}$ & 0.221 & $<0.001$ & 0.109 & $<0.001$ \\
\hline
\end{tabular}

exposure to pollutants such as toxic metals. Metals are important constituents widely used in different industrial processes and can be present in biological fluids, namely urine, as a consequence of occupational exposure. Although atomic absorption spectrometric techniques, (flame or graphite furnace mode; FAAS and GFAAS) are a powerful analytical tool for the determination of trace metals. Determination of metals in urine, serum and blood samples is very difficult due to various factors, particularly low metal content and high salt content of the sample matrix. The use of a separation and preconcentration technique in the analytical process can solve these problems and lead to easy determination of trace metals in urine, serum and blood samples. There are many methods for preconcentration/separation of trace heavy metals from human biological samples [24]. Komatsu et al reported determination of $\mathrm{Li}$ in whole blood by using colorimetric determination of lithium ions with a low limit of detection about $0.054 \mathrm{mM}$, and the coefficient of variance below $6.1 \%$. A portion of whole blood has been placed on the end of the separation unit, plasma in the sample is automatically transported to the detection unit, which displays a diagnostic color [25]. This method has higher LOD and RSD\% as compared to the USADIL- $\mu$-SPE procedure. Also, a wide linear range 
between 0.1-0.4 $\mathrm{mg} \mathrm{L}^{-1}$ was used based on APDC/ IL/GONPs. Suherman et al reported electrochemical detection and quantification of lithium ions in authentic human saliva using $\mathrm{LiMn}_{2} \mathrm{O}_{4}$-modified electrodes. The sensing strategy is based on an initial galvanostatic delithiation of LMO followed by linear stripping voltammetry (LSV) to detect the re-insertion $\mathrm{Li}^{+}$in the analyte. The process was investigated using powder X-ray diffraction (PXRD) and voltammetry. LSV measurements reveal a measurable lower limit of $50.0 \mu \mathrm{M}$ in both $\mathrm{LiClO}_{4}$ aqueous solutions and synthetic saliva samples [26]. Filippini et al showed that the determinants of serum manganese levels in an Italian population. They employed an inductively coupled plasmasector field mass spectrometry (ICP-SFMS) instrument for Mn determination in medium resolution mode. The LOD for Mn-peaks in SEC-ICP-DRC-MS was calculated as $3 \sigma$-criterion and found between $28-35 \mathrm{ng} \mathrm{L}^{-1}$ [27]. This method is expensive and sample preparation needs before analysis. On the other hand, as normal level $\mathrm{Mn}$ in serum or blood $\left(\mu \mathrm{gL}^{-1}\right)$, the USA-DIL$\mu$-SPE procedure has a sufficient rate. Zabłocka et al reported an applied method for evaluation $\mathrm{Zn}, \mathrm{Cu}$ and $\mathrm{Mn}$ in serum /whole blood samples and their relation to redox status in lung cancer patients. In their study for whole blood preparation, $0.5 \mathrm{ml}$ was performed twice by microwave -technique wet mineralization in a closed system using MLS 1200 Mega, with mixture $1: 5$ of $\mathrm{H}_{2} \mathrm{O}_{2}(30 \%)$ and $\mathrm{HNO}_{3}(69-70 \%)$ and graphite furnace atomization was used for the determination of $\mathrm{Mn}$. They reported analytical values of $\mathrm{Zn}, \mathrm{Mn}$ and $\mathrm{Cu}$ were: $8.97 \mathrm{mg} \mathrm{L}^{-1}, 47.3$ $\mu \mathrm{g} \mathrm{L}^{-1}$ and $2.47 \mathrm{mg} \mathrm{L}^{-1}$, respectively. Mean accuracy $(\mathrm{n}=6)$ was as follows: $98,3 \%(\mathrm{Zn}), 105.9 \%(\mathrm{Mn})$ and $91.6 \%(\mathrm{Cu})$ which was comparable to the USADIL- $\mu$-SPE procedure for Mn determination [28]. In this study, we used the USA-D- $\mu$-SPE procedure based on APDC/IL/GONPs for micro-extraction and determination of lithium and manganese concentration in human biological samples. The surface charge of GONPs is negative so, the electrostatic attraction between negatively charged of adsorbent and positive charge of $\mathrm{Li}^{+}$and $\mathrm{Mn}^{2+}$ ions have occurred at optimized $\mathrm{pH}=6$. In addition, quantitative extraction of more than $95 \%$ was observed in the optimized sample volume. It was also noticed that higher sample volumes, partially solubilized the ionic liquid phase, leading to nonreproducible results and increased the amount of GONPs. It was also observed that the extraction efficiency was remarkably affected by GONPs and IL amount, so they were examined within the range of 2 to $60 \mathrm{mg}$ and 10 to $100 \mathrm{mg}$ for GONPs and IL, respectively. Quantitative extraction was observed at $25 \mathrm{mg}$ of GONPs for Li and Mn which was lower or similar amount as compared to other methods. The USA-DIL- $\mu$-SPE method was applied to determine $\mathrm{Li}^{+}$and $\mathrm{Mn}^{2+}$ for $1 \mathrm{~mL}$ and $10 \mathrm{ml}$ in human biological samples, respectively. The spiked serum and blood were prepared to demonstrate the reliability of the method for extraction and determination of $\mathrm{Mn}$ and Li. At optimized condition, the LOD of the method was found $0.03 \mathrm{mg} \mathrm{L}^{-1}$ for $\mathrm{Li}$ and $0.026 \mu \mathrm{gL}^{-1}$ for $\mathrm{Mn}^{2+}$ and working ranges was found $0.3-1.0 \mathrm{mg} \mathrm{L}^{-1}$ for $\mathrm{Li}$ and $0.08-5 \mu \mathrm{gL}^{-1}$ for $\mathrm{Mn}$. The mean of $\mathrm{Mn}^{2+}$ and $\mathrm{Li}^{+}$concentration in blood, urine and serum of MS patients and healthy people were determined by the USA-DIL- $\mu$-SPE procedure which was near to recently reported. The results showed that the concentration of $\mathrm{Li}^{+}$and $\mathrm{Mn}^{2+}$ ions in the blood, urine and serum of MS patients were higher than healthy people, $\left(6.19 \pm 0.29 \mu \mathrm{gL}^{-1}\right.$ vs $3.42 \pm 0.15 \mu \mathrm{gL}-$ 1, $\mathrm{P}<0.05$ for $\mathrm{Li}$ in the blood and $6.83 \pm 0.31 \mathrm{mgL}^{-1}$ vs $2.42 \pm 0.90 \mathrm{mgL}^{-1}, \mathrm{P}<0.05$ for $\mathrm{Mn}$ in urine). The adsorption capacity of APDC/IL/GONPs for $\mathrm{Li}^{+}$and $\mathrm{Mn}^{2+}$ ions were found at $148.5 \mathrm{mg} \mathrm{g}^{-1}, 122.3 \mathrm{mg} \mathrm{g}^{-1}$, respectively. This study showed that the application of APDC/IL/GONPs as the SPE procedure is a fast and low-cost separation route without nonabsorbent loss. Therefore, APDC/IL/GONPs is considered to be excellent and potential adsorbent for the extraction of $\mathrm{Li}^{+}$and $\mathrm{Mn}^{2+}$ ions in human biological fluids.

\section{Conclusions}

A novel APDC/IL/GONPs was used for separation/ extraction and determination of $\mathrm{Li}$ and $\mathrm{Mn}$ ions in human blood, serum and urine samples by the USA-DIL- $\mu$-SPE procedure. The IL ([HMIM] 
$\left.\left[\mathrm{PF}_{6}\right]\right)$ property was helped to collect the GONPs phase from the liquid phase in the bottom of the conical tube. By the proposed procedure, a fast and simple, efficient extraction and perfect separation were achieved at $\mathrm{pH} 5-7$ (RSD $\leq 5 \%)$. The APDC ligand coated on nanoparticles of GONPs enhanced the $\mathrm{Li}$ and $\mathrm{Mn}$ extraction in blood samples. By the USA-DIL- $\mu$-SPE procedure many advantages such as good reusability, perfect separation, low cost, and high recovery (more than 95\%) were achieved as compared to ICP-MS and other techniques. Therefore, the separation and determination of $\mathrm{Li}$ and $\mathrm{Mn}$ ions in human samples were achieved in optimized conditions. The results showed the detection limits (LOD), pre-concentration factor and the linear range of the method for $\mathrm{Li}$ and $\mathrm{Mn}$ were obtained $\left(0.03 \mathrm{mg} \mathrm{L}^{-1}\right.$ and $\left.0.025 \mu \mathrm{g} \mathrm{L}^{-1}\right),(9.72$, 10.2) and (0.1-0.4 $\mathrm{mg} \mathrm{L}^{-1}$ and $\left.0.08-1.5 \mathrm{mg} \mathrm{L}^{-1}\right)$, respectively. The adsorption capacity of graphene oxide for lithium and manganese was achieved at $148.5 \mathrm{mg} \mathrm{g}^{-1}$ and $122.3 \mathrm{mg} \mathrm{g}^{-1}$, respectively. Validation of the method was performed by spiking samples and standard reference materials (SRM) in the human blood, serum and urine.

\section{Acknowledgements}

The authors wish to thank the Azad University of Medical science, Petroleum Industry Health Research Institute (IPIHRI), and the Iranian Research Institute of Petroleum Industry (RIPI) for supporting this work.

\section{References}

[1] V.L. Feigin, A.A. Abajobir, K.H.Abate, F. Abd-Allah, A.M. Abdulle, S.F. Abera, Global regional and national burden of neurological disorders during 1990-2015: a systematic analysis for the Global Burden of disease study 2015, Lancet Neurol.,16 (2017) 877-897. https://doi.org/10.1016/ S1474-4422(17)30299-5

[2] M.D. Napier, Heavy metals, organic solvents, and multiple sclerosis: an exploratory look at gene-environment interactions, Arch. Environ. Occup. Health, 71 (2016) 26-34. https:// doi.org/10.1080/19338244.2014.937381

[3] A. Karimi, K. Bahrampour, M.A.M. Moghaddam, G. Asadikaram, G. Ebrahimi, M. Torkzadeh-Mahani, Evaluation of lithium serum level in multiple sclerosis patients: A neuroprotective element, Mult. Scler. Relat. Disord., 17 (2017) 244-48. https://doi. org/10.1016/j.msard.2017.08.019

[4] D.F.D. Mota, B. D. Leverson, J. L. Goossens, Lithium in medicine: mechanisms of action, Met. Ions Life Sci., 16 (2016) 557-584. https://doi.org/10.1007/978-3-319-21756-7_15

[5] C. Garza-Lombó, Y. Posadas, L. Quintanar, M. E. Gonsebatt, R. Franco, Neurotoxicity linked to dysfunctional metal ion homeostasis and xenobiotic metal exposure: redox signaling and oxidative stress, Antioxid. Redox Signal, 28 (2018) 1669-1703. https://doi.org/10.1089/ars.2017.7272

[6] P. Chen, S. Chakraborty, S. Mukhopadhyay, E. Lee, M. M.B. Paoliello, A. B. Bowman, M. Aschner, Manganese homeostasis in the nervous system, J. Neurochem., 134 (2015) 601-610. https://doi.org/10.1111/jnc. 13170

[7] R. Nicholas, R. Waqar, Multiple sclerosis, Am. Fam. Physician, 87 (2013) 712-714. https:// pubmed.ncbi.nlm.nih.gov/23939450/

[8] A. Winckelmann, D. Morcillo, S. Richter, S. Recknagel, J. Riedel, J. Vogl, U. Panne, C. Abad, Determination of lithium in human serum by isotope dilution atomic absorption spectrometry, ChemRxiv, (2021). https://doi. org/10.26434/chemrxiv.14130080.v1

[9] M. Aliasgharpour, H. Hagani, Evaluation of lithium determination in three analyzers: flame emission, FAAS and ion-selective electrode, Am. J. Med., 1 (2009) 244-246. https://dx.doi.org/10.4297\%2Fnajms.2009.5244

[10] M.Aliomrani, M.A. Sahraian, H. Shirkhanloo, M. Sharifzadeh, M. R. Khoshayand, M. H. Ghahremani, Blood concentrations of cadmium and lead in multiple sclerosis patients from Iran, Iran. J. Pharm. Sci., 15 (2016) 825-833. https://www.ncbi.nlm.nih. gov/pubmed/28243279 
[11] M. de Oliveira, T.M. Gianeti, F.C. da Rocha, P.N. Lisboa-Filho, M. Piacenti-Silva, A preliminary study of the concentration of metallic elements in the blood of patients with multiple sclerosis as measured by ICPMS, Sci. Rep., 10 (2020) 13112. https://doi. org/10.1038/s41598-020-69979-9

[12] U. Kramer, M. Kress, H. Reinauer, M. Spannagl, P. Kaiser, Candidate reference measurement procedures for chloride, potassium, sodium, calcium, magnesium, and lithiumby inductively coupled plasma(isotope dilution) sector field mass spectrometry (ICP-(ID) SFMS) in serum, Clin. Lab., 59 (2013) 1017-1029. https://doi.org/10.7754/ clin.lab.2012.120902

[13] J.Lin, Y.Liu, Z. Hu, L. Yang, K. Chen, H.Chen, K. Zong, S. Gao, Accurate determination of lithium isotope ratios by MC-ICP-MS without strict matrix-matching by using a novel washing method, J. Anal. At. Spectrom., 31 (2016) 390-397. https://doi.org/10.1039/ C5JA00231A

[14] A. Winckelmann, S. Nowak, S. Richter, S. Recknagel, J. Riedel, J. Vogl, U. Panne, C. Abad, High-Resolution atomic absorption apectrometry aombined withmachine learning data processing for isotope amount ratio analysis of lithium, ChemRxiv, (2021). https:// doi.org/10.26434/chemrxiv.13583024.v1

[15] E. Marguí, R. Dalipi, E. Sangiorgi, M. B. Štefan, K. Sladonja, V. Rogga, J. Jablan, Determination of essential elements ( $\mathrm{Mn}, \mathrm{Fe}$, $\mathrm{Cu}$ and $\mathrm{Zn}$ ) in herbal teas by TXRF, FAAS and ICP-OES, Xray Spectrom., (2021)1-10. https://doi.org/10.1002/xrs.3241

[16] N. Solovyev, M. Vinceti, P. Grill, J. Mandrioli, B. Michalke, Redox speciation of iron, manganese, and copper in cerebrospinal fluid by strong cation exchange hromatographysector field inductively coupled plasma mass spectrometry, Anal. Chim. Acta, 973 (2017) 25-33. https://doi.org/10.1016/j. aca.2017.03.040

[17] H. Shirkhanloo,M. Ghazaghi, M. M.Eskandari,
Cloud point assisted dispersive ionic liquidliquid microextraction for chromium speciation in human blood samples based on isopropyl 2-[(isopropoxycarbothiolyl) disulfanyl] ethane thioate, Anal. Chem. Res., 10 (2016) 18-27. https://doi.org/10.1016/j.ancr.2016.10.002

[18] D. Zou, Y. Qing, Y. Li, M. Liu, Y. Yang, Determination of manganese (VII), chromium (VI) and nickel (II) in medicinal herb samples by cloud point extraction and high-performance liquid chromatography, J. Iran. Chem. Soc., 11 (2014) 415-422. https://doi.org/10.1007/s13738-013-0313-6

[19] K. M. Diniz, C. R. T. Tarley, Speciation analysis of chromium in water samples through sequential combination of dispersive magnetic solid-phase extraction using mesoporous amino-functionalized $\mathrm{Fe}_{3} \mathrm{O}_{4} / \mathrm{SiO}_{2}$ nanoparticles and cloud point extraction, Microchem. J., 123 (2015) 185-195. https://doi.org/10.1016/j. microc.2015.06.011

[20] M. Rezvani, AA. Asgharinezhad, H. Ebrahimzadeh, N. Shekari, A polyanilinemagnetite nanocomposite as an anion exchange sorbent for solid-phase extraction of chromium (VI) ions, Microchim. Acta, 181 (2014) 1887-1895. https://doi.org/10.1007/ s00604-014-1262-1

[21] M. K. Abbasabadi, A. Rashidi, S. Khodabakhshi, Benzenesulfonic acid-grafted graphene as a new and green nanoadsorbent in hydrogen sulfide removal, J. Nat. Gas Sci. Eng., 28 (2016) 87-94. https://doi. org/10.1016/j.jngse.2015.11.043

[22] J. Hummers, S. William, R. E. Offeman, Preparation of graphitic oxide, J. Am. Chem. Soc., 80 (1958) 1339. https://doi.org/10.1021/ja01539a017

[23] M. K. Abbasabadi, D. Azarifar, Magnetic $\mathrm{Fe}_{3} \mathrm{O}_{4}$-supported sulfonic acidfunctionalized graphene oxide $\left(\mathrm{Fe}_{3} \mathrm{O}_{4} @\right.$ GO-naphthalene- $\mathrm{SO}_{3} \mathrm{H}$ ): a novel and recyclable nanocatalyst for green onepot synthesis of 5-oxo-dihydropyrano [3, 2-c] chromenes and 2-amino-3-cyano-1, 
4, 5, 6-tetrahydropyrano [3, 2-c] quinolin5-ones, Res. Chem. Intermed., 45 (2019) 2095-2118. https://doi.org/10.1007/s11164018-03722-y

[24] R. M. Cespón-Romero, M. C. Yebra-Biurrun, Determination of trace metals in urine with an on-line ultrasound-assisted digestion system combined with a flow-injection preconcentration manifold coupled to flame atomic absorption spectrometry, Anal. Chim. Acta, 609 (2008) 184-191. https://doi. org/10.1016/j.aca.2008.01.002

[25] T. Komatsu, M. Maeki, A. Ishida, H. Tani, M. Tokeshi, Based device for the facile colorimetric determination of lithium ions in human whole blood, ACS Sens., 5 (2020) 1287-1294. https://doi.org/10.1021/ acssensors.9b02218

[26] A. L. Suherman, B. Rasche, B. Godlewska, P. Nicholas, S. Herlihy, N. Caiger, P. J. Cowen, R. G. Compton, Electrochemical detection and quantification of lithium ions in authentic human saliva using $\mathrm{LiMn}_{2} \mathrm{O}_{4}$-modified electrodes, ACS sens., 4 (2019) 2497-2506. https://doi.org/10.1021/acssensors.9b01176

[27] T. Filippini, B. Michalke, P. Grill, C. Malagoli, M. Malavolti, L. Vescovi, S. Sieri, V. Krogh, A. Cherubini, G. Maffeis, R. Lucchini, Determinants of serum manganese levels in an Italian population, Mol. Med. Rep., 15 (2017) 3340-3349. https://doi.org/10.3892/ mmr.2017.6379

[28] K. Zabłocka-Słowińska, S. Płaczkowska, A. Prescha, K. Pawełczyk, I. Porębska, M. Kosacka, L. Pawlik-Sobecka, H. Grajeta, Serum and whole blood $\mathrm{Zn}, \mathrm{Cu}$ and $\mathrm{Mn}$ profiles and their relation to redox status in lung cancer patients, J. Trace Elem. Med. Biol., 45 (2018) 78-84. https://doi. org/10.1016/j.jtemb.2017.09.024 